\title{
Metabolic changes
}

As accidents become more frequent and more serious with increasing speed and degree $\stackrel{\omega}{\circ}$ assault, and as surgeons become more venturesome, the degree of trauma induced increases. It is all the more essential, therefore, that we also try to understand the nature of the mangy changes in the rest of the body and the disturbed metabolism consequent on injury. Interst in this important field between wars has been meagre apart from a few small groups who haje kept up a sustained interest. It is hoped that a renewed responsibility to the study of the injured will now be forthcoming.

In 1942 the writer reviewed existing knowledge in what he termed the 'post-shock metabotic response to injury' and introduced the terms 'ebb' and 'flow' respectively for the early period of depressed vitality or metabolism consequent on the injury, and the latter for the increased metabolism which ensues in those who recover. It is of interest that these concepts are süll useful.

Dr H. B. Stoner from his long experience in this field has found it convenient to divide thege changes into haemodynamic, neuro-endocrine, and metabolic, stressing the last as probaifly the most important since bodily function depends on energy transformation. He has used the term 'necrobiosis', first applied by Sir Ashley Miles, for the state where the ebbing \&of vitality continues and eventually reaches an apparently irrecoverable stage. It is (he intensity and duration of these changes in terms of heat production which vary with the individual, and involved in this are the state of nutrition in respect of protein reserves, 蛋e nature of the injury, and the environmental temperature. In the flow period the heat producti官n is increased through changes at the peripheral sites of thermogenesis.

Contrary to expectations the oxygen supply to the main organs during the acute 'eto. phase can be adequate. The changes characteristic of tissue hypoxia do not tend to occur unil later when death seems certain. The mechanism of the decreased heat production during 'ebb' phase is due to failure of oxygen utilization. During the 'flow' period heat producton and oxygen consumption are increased. In the rat and in man (Cairnie, Campbell, Cuthbertsôn, and Pullar, 1957) increased oxidation of protein equivalent to the extra nitrogen and sulphir found in the urine consequent on injury during the first 10-12 days can account for the exfra heat production.

Erici (1954 and 1957) was one of the earliest experimental observers to point out the be ficial effects of a higher temperature on the healing of skin wounds in rabbits, but cliniçal observations on the speed of healing of burns in the Middle East had been reported during World War Two.

Apparently independently Caldwell (1962) recorded his important observation that 冚e increased heat production and urinary nitrogen following experimental burns could 5 be eliminated when the environmental temperature was raised to $30^{\circ} \mathrm{C}$. Deaths of experimental animals were also reduced at the higher temperature and healing was hastened. Dr Stofer describes how important it is to differentiate between the normal increase in heat production consequent on the injury and the additional increase in metabolic rate which occurs if evaporative water loss is also increased as in burns. At each stage it is important to tryoto determine if the injury is primarily affecting the peripheral or central nervous control mechanisms for thermogenesis.

Dr J. W. L. Davies, of the Medical Research Council's Industrial Injuries and Burns U⿳亠丷厂巾, it, 
following up the close correspondence between the increased rate of nitrogen excretion and the increase in resting metabolic rate both in fractures and burns, has with his Swedish collaborators Barr, Birke, Liljedahl, and Plantin (1968), demonstrated the beneficial effect of a warm environment $\left(32^{\circ} \mathrm{C}\right)$ on protein metabolism. They have shown that the catabolism of plasma albumin and $\gamma \mathrm{G}$ globulin increases as the severity of burns increases and that with burns the catabolic rate of these two proteins is reduced by nursing the patients at $32^{\circ} \mathrm{C}$. At this environment less albumin is catabolized and less $\gamma \mathrm{G}$ globulin is synthesized. In skeletal injury there is less disturbance compared with the low albumin, high $a_{2^{-}}$, and $\gamma \mathrm{G}$ concentrations observed in burned patients but unexpectedly these do not appear to be affected by the severity of the injury (see also Cuthbertson, Tilstone, and Green, 1969).

In fracture cases and in the rat we have also observed the effect of a temperature of $30^{\circ} \mathrm{C}$ in reducing the catabolism of protein and heat production (Campbell and Cuthbertson, 1967; Cuthbertson, Smith, and Tilstone, 1968; Cuthbertson and Tilstone, 1969a; Tilstone and Cuthbertson, 1970) and in reducing the fall in albumin and rise in $\gamma \mathrm{G}$ globulin.

Dr John M. Kinney, as the result of his studies in his Metabolic Unit in the Surgical Service of the Presbyterian Hospital, New York, considers that some of the most outstanding components of the metabolic response to injury are an increase in urinary nitrogen excretion for any given nitrogen intake and a tendency toward hyperglycaemia, glycosuria, and a diabetic-like glucose tolerance test. His own extensive studies on the resting metabolic expenditure of surgical patients by the methods of indirect calorimetry, utilizing prolonged measurements of resting gas exchange and nitrogen balance, have added much quantitative knowledge to this. His data confirm that increases in resting energy expenditure are demanded. After elective operation there is no change but with multiple fractures the demands on resting energy are increased up to $20 \%$ for one to three weeks (agreeing with my findings in 1932), in major sepsis they are up to $40 \%$ for the period of acute inflammation, and in major burns are often from 40 to $100 \%$ above normal during open treatment on a conventional hospital ward: these latter values agree with those of the Swedish team of Barr et al (1968).

Studies in surgical patients indicate that the turnover and oxidation rates of glucose are not significantly altered by elective operation but both are significantly increased following major trauma and sepsis. Therefore, it is suggested that the nitrogen loss after injury is related to the requirements for carbohydrate intermediates and the control of gluconeogenesis rather than to general requirements for two-carbon fuel.

Dr Nahas, you will find, has integrated for us the effects of the failure of various organ functions which tend to disturb acid-base equilibrium and produce acidaemia. The degree of acidaemia is a function of the severity of the impairment of organ function during shock, mostly of heart and lungs. The physiological effects are well documented. Acidosis profoundly alters the sympatho-regulation, producing an increase in catecholamine synthesis and release, and at the same time decreasing the metabolic activity of these amines.

Dr Nahas emphasizes that an acid $p \mathrm{H}$ inhibits the ability of the body to mobilize and utilize its fuel stores and to increase metabolism above basal levels: the normal reaction to stress is inhibited by acid $p \mathrm{H}$. Compensation for this would appear to usher in the 'flow' stage.

Injury, by physical or chemical agents, is a threat to homeostasis. The various transmitters and mediators in the response-and the metabolic response to injury involves a multiplicity of effectors and homeostatic regulators-are neural or hormonal, the latter including the 'local hormones' such as bradykinin (see Cuthbertson and Tilstone, 1969b).

Whatever the reason for the additional protein catabolism that usually follows injury and which is most likely linked to a need for glucogenic materials for extra energy purposesand here protein reserves are a readily available source-nevertheless the need for this is clearly not sufficiently pressing to be obligatory in the same degree in patients at high environmental temperatures $\left(30-32^{\circ} \mathrm{C}\right)$. 
References

Barr, P.-O., Birke, G., Liljedahl, S.-O., and Plantin, L.-O. (1968). Oxygen consumption and water loss during treatment of burns wh

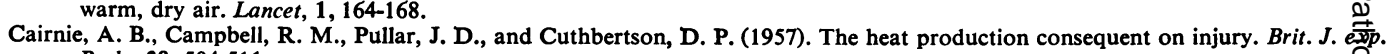
Path., 38, 504-511.

Caldwell, F. T. (1962). Metabolic response to thermal trauma II. Nutritional studies with rats at two environmental temperatures. Surg., 155, 119-126. Campbell, R. M., and Cuthbertson, D. P. (1967). Effect of environmental temperature on the metabolic response to injury. Quar! ${ }^{\prime} J$.
exp. Physiol., 52,114-129.

Cuthbertson, D. P. (1932). Observations on the disturbance of metabolism produced by injury to the limbs. Quart J. Med., 25, 233-2 96.

Cuthbertson, D. P. (1942). Post-shock metabolic response. Lancet, 1, 433-437.

Cuthbertson, D. P., Smith, C. M., and Tilstone, W. J. (1968). The effect of transfer to a warm environment $\left(30^{\circ} \mathrm{C}\right)$ on the metabolic response to injury. Brit. J. Surg., 55, 513-516.

Cuthbertson, D. P., and Tilstone, W. J. (1969a). Metabolism during the post injury period. Advanc. clin. Chem., 12, 1-55.

Cuthbertson, D. P., and Tilstone, W. J. (1969b). The metabolic and hormonal response of the body to injury. In Pathology of the Huragn Adrenal Gland, part 1, edited by T. Symington. Livingstone, Edinburgh and London.

Cuthbertson, D. P., Tilstone, W. J., and Green, J. A. (1969). Immunoglobulins in injured patients. Lancet, 1, 987-988.

Erici, I. (1954). An experimental study of wound healing (Swedish). Svenst. kir. Fören. Förh., 29th May, pp. 34-35. Also abstr. in Nord. Med. (1955), 53, 128

Erici, I. (1957). Effect of environmental temperature on the rate of wound healing. Acta chir. scand., 112, 345-347.

Tilstone, W. J., and Cuthbertson, D. P. (1970). The protein component of the disturbance of energy metabolism in trauma. In Eneto Metabolism in Trauma, Ciba Foundation Symposium 17-18 Fet., 1970. In press. 